\title{
Interrogating Concession, Trust and Forgiveness in Saare/Tsaragi, Peace Building, Nigeria: Implication for Conflict Management in Africa.
}

\author{
Alao, David Oladimeji Ph.D. \\ Department of Political Science and Public Administration Ilishan-Remo, Ogun State, Nigeria
}

\begin{abstract}
Violent conflicts remain problematic globally. Saare/ Tsaragi communities, Kwara State, Nigeria cohabited peacefully from about 1808 till 2000 and by 2008 had witnessed three violent conflicts due to boundary issues. The study examined the relevance of forgiveness, concession and trust in peace building. A descriptive that adopted qualitative methods combining primary and secondary data sources while purposive sampling method was used to select 400 respondents from the two communities. It found that $77 \%$ suffered injury, 74.5 percent of the respondents were willing to forgive, 83.3 percent were ready for concession, while 32 percent agreed to trusting the opposing party. The study in addition found that government lacked the political will to transform the conflict and concluded that the issues of the conflicts were not beyond resolution but trust building constituted the greatest challenge. The study recommended depoliticization strategy combined with integrative negotiation by the two communities in areas of granting concession. In addition, the government must develop strong political will to monitor early warning signals, remain neutral and support the community initiatives through peace education, economic and social supports in order to enhance trusting relations. The implication for other conflicting societies is that attention by peace agents should equally be focused on social and structural peace building than concentration on political peace building.

Key words: Conflict, forgiveness, concession, trust, negotiation, Peace, social and structural peace building .

213 words
\end{abstract}

Key words: Conflict, forgiveness, concession, trust, negotiation and Peace. 230 words

\section{Introduction}

The healing process after direct violence constitutes one of the greatest challenges for the conflict parties as well as the peace agents including government, professional mediators or private individuals and organizations. Prominent among the challenges that must be encountered and overcame are the issues of ensuring sincere communication, psychological strain, injury suffered by the victims of the conflict. Others include trust building, granting of concession and forgiveness in the course of peace building. This study will focus on trust building, granting of concession and forgiveness.

In a conflict situation, individuals can be the victims or agents, while in some situation the same person might be the agent and victim. According to Galtung (2000), peace could be seen as the absence of direct violent. Reychler (2001) notes that peace building goes beyond problem solving or conflict management but it attempts to fix the core problems that underlie the conflict and change the pattern of interaction of the parties involved.

Saare, a Yoruba community, and Tsaragi communities Nupe ethnic group in Kwara State, Nigeria cohabited peacefully inspite of nebulous boundaries from 1808 until 2000 when they witnessed direct violence on account of boundary disputes leading to loss of lives and properties. The creation of Ifelodun Local Government (LG) with Saare as Headquarters was a trigger factor, making the boundary to become a sensitive issue. The resurgence of direct violence on three occasions from 2000-2008 was a reflection of defective post conflict peace building as in other instances of conflict in Africa. It motivate this study to examine the issues such as forgiveness, concession and trust that are part of the elements required for successful peace building and the lessons for other conflict zones. The study argued that resurgence of direct violence diverts the attention of government and citizenry from socio-economic development programmes, excessively stresses the limited resources available and led to traumatic experiences by the victims. An alternative conflict resolution mechanisms was therefore considered necessary to overcome the challenges.

The data was extracted from the researcher's works on Saare/Tsaragi in (2011/2012) and a descriptive qualitative research design. The population of the study area was 15,889 consisting of adults of eighteen years and above, with three thousand, two hundred and fifty two (3252) in Tsaragi and twelve thousand, six hundred and thirty seven $(12,637)$ in Saare. Each of the communities was treated as an entity and a sample of two hundred respondents from each were purposively selected to reflect the salient characteristics required for the success of the study. The study combined primary and secondary sources of data collection. The processed data 
collected were presented as tables with frequency distribution while the analysis was descriptive on the basis of which conclusions and recommendations were made.

\section{Theoretical framework.}

Like a human being, every conflict, by its usual nature and manifestation is beyond a single causative element and this demands uniting effective frameworks to the prevailing circumstances as every conflict is unique. The study primarily adopted Galtung (2010) Transcend Model to analyze the emergence, growth of the conflict and mechanism for peace. To understand the parties that might be helpful in facilitating peace through the willingness to grant concession, forgiveness and building trusting relations by non-violence means, the Multi-Tracks Diplomacy of McDonald and Diamond (1996) was adopted.

Transcend Model according to Galtung (2010) identifies the basic elements that differentiate it from others in the field of conflict resolution. First, it focuses on peace, a relation between parties and not on security approach while empathic and creative-nonviolent approach has the tendency to produce peace which is the best approach to 'security'. Second, peace approach calls transformation of another relation between parties, (McDonald and Diamond, 1996, Lederach, 1995). Third, the approach goes beyond the goals of the parties by creating a new reality. Fourth, transcend approach starts with one party at a time, in a deep dialogue, and in a joint creative search for a new reality. Fifth, the model does not view conflict as totally bad, as it can positively enhance the quality of relationship and create new opportunities.

Focusing on what happens before violence, Galtung (2000) in Nicolaides, (2008) presented conflict triangle consisting behaviours, attitudes and contradictions. Galtung observes that there must be polarization before direct violence and before polarization, some level of aggression must be in existence that arose from 'blocked goals because self and/or other pursue incompatible goals' (Gurr (1939), Feierbends and Ivo (1966) cited in Anifowose (2006)). Richardson \& Sen (1996) add other factors such as historical legacy of mistrust, victim mentality, and relative deprivation must equally be present in sizeable quantity. Enloe (1973) identifies the transition to modernity intensifies the political implications of inter-ethnic contact leading to conflicts. However, extant literature note that not all aggressions lead to violence as some may prefer to suffer in silence (Anifowose, (2006) and the presence of respected figures that can mobilize masses for violence without real aggression, this LeBlanc (2003) refers to as "the chiefs."

Galtung (2000) opines that any conflict has its real or identifiable source that might include ethnic nationalism, religion, exclusion of a majority group, authoritarianism, poverty, unmet basic needs, political oppression, and marginalization and religion extremism. These sources according to Jean and Goss-Mayer in Nicolaides (2008) might constitute the conflict pillars that must be created and sustained to make a conflict turn violent. The significance of identifying the sources of the conflict is to provide the logical means to contribute to the peace building process, as the sources should be attacked rather than the pattern or the manifestation.

Transcend Approach is therefore based on mediators meeting the parties one-to-one, dialoguing, and searching for new realities that would accommodate individual group interests. Transcend model as Galtung (2010) notes overcome the weakness of other models in that while States tend to be triggered into serious action not by conflicts but by acts of violence, it emphasizes the transformation of the conflict. This position agrees with Osaghae (2000) cited in Zartman (2000) that it is the futility of efforts to resolve the conflicts in Africa that has partly provoked the search for more creative and contextual approaches to conflict resolution. For inclusive approach in conflict resolution Multi-Track Diplomacy as postulated by Notter and Diamond (1996) is an adaptive mechanism towards enduring peace process though the process. It proposes the participants to make the process of resolution inclusive that is elastic in nature to accommodate the uniqueness of conflicts. It is tedious and time consuming that requires a high sense of focus on the goals required to supporting all the tracks in order to achieve peace.

Transcend models was criticized by Boulding (1977), Kay (2009), Bawer (2007) and Cox and Kay (2009) that Galtung did not produce practical prescriptions for managing or resolving global conflicts because "ideology always trumps objectivity and pragmatism" while others critics observed that the "scholarship" exists to put a respectable face on "Western self-loathing.".

In response to the criticisms, Krasner (2004), Doyle and Sambanis (2006), and Morris, Hoffman, Peachey, (2009) note that critics underestimated the development of detailed interdisciplinary, theoretical, methodological, and empirical research into the causes of violence and dynamics of peace that has occurred via academic and policy networks around the world- Also, the development of UN and major donor policies have been heavily influenced through the contribution of the advocates of peace that are regarded by them as leftists. In effect, the transcend model of Galtung that this paper is adapting to negation as an alternative viable method of achieving enduring peace. 


\section{Peace-building}

\section{Conceptual clarification}

Peace building could be understood from two perspectives. The first as used by UN Secretary General Boutros Ghali in his 1992 Agenda for peace. The term "Peace Building" is seen as part of continuum ranging from preventive diplomacy, to peace making, to peace keeping, and finally to post- conflict peace building. This implies that it consists of a wide range of activities associated with capacity building, reconciliation, and societal transformation. This phase of peace process takes place after peace- making and peacekeeping. Second, many non-governmental organizations assume peace building as a compound term encompassing not only long term transformative efforts, but also peacemaking and peacekeeping. To these organizations, it includes early warning and response efforts, violent prevention, advocacy work, civilian and military intervention, humanitarian assistance, ceasefire, agreements and the establishment of peace zones.

For the purpose of this study, it identifies with Maiese (2003) that peace building is the process that facilitates the establishment of durable peace and tries to prevent the recurrence of violence by addressing root causes and effects of conflict through reconciliation, institution building, and political as well as economic transformation. This explains why Hauerudraaten. (2003) views sustainable peace as characterized by absence of physical and structural violence, the elimination of discrimination, and self sustainability. Reychler, (2001) adds that peace building involves moving towards this environment goes beyond problem solving or conflict management. It attempts to fix the core problems that underlie the conflict and change the patterns of interaction of the involved parties. The aim, according to Lederach. (1997) is to move a given population from a condition of extreme vulnerability and dependency to that of self - sufficiency and well-being. To achieve this, parties must replace the spiral of violence and destruction with a spiral of peace and development, and create an environment conducive to self-sustaining and durable peace (Maiese, 2003).

This study identifies with three distinctive types of peace building that are complementary in nature.

These are political peace building which is about agreements that provide the overall context for understanding the relationships of the various parties and their resources. It is worth noting that the efforts of governments all over the world are centred on political peace building activities. Structural peace building activities deals with creating systems of behaviour, instruction, and concerted action needed to support the embodiment or implementation of a peace culture (Notter \& Diamond, 1996). It has to do with building an economic, military and community infrastructure that provide concrete and realistic awareness through which a new peace system might find expression. Social peace building is the grassroots portion of the peace building process that consists of management of feelings, attitudes, opinions, and beliefs, values that are held and shared between peoples, individually and in groups. Governments often downplay the significance of social peace building in favour of political and structural types and this explains while true reconciliation is achieve in their interventions to resolve conflicts.

\section{Forgiveness}

Forgiveness presupposes the existence of wrong doing, sin or injury caused an individual, a group of people or both. The wrong doing could be as a result of cultural, structural or direct violence (Murphly and Hampton, 1988). Enright, et al (1996) believe that the offense is an objective reality and not just a perception of the offended. For instance, Saare/Tsaragi conflict had recorded three violent confrontations since 2000. The direct violence of November 2-3, 2008 alone claimed 9 lives and the destruction of sixty six buildings (Kwara State Gazette No. 7. Vol. 43 of April, 2009). Those whose lives are chained down on account of injury suffer as observed by the Foundation for Inner Peace, (1971) are 'victims of something else', a thing outside themselves and for which they had no reason to be held responsible. Such people according to Musser, (2012), when negativity from their past repeatedly comes into their thoughts often hold tenaciously to the consequences of the past and produce a vicious circle of anger and agony that can instigate vengeance.

Forgiveness for the purpose of this study is seen as the inner conviction that is divine in nature, to let go the feelings and planned actions to revenge on account of injury suffered from probably known agents. It requires the development of strong will not to allow the previous agony experienced or told to evoke the sentiment to revenge and also to forgive self for perceived or real wrong doing (Borris, 2003). This to a large extent is as an element of the healing process in peace building that is believed to run contrary to human nature that will always seek for vengeance. This explains while it involves a process which required a change in one's perception, and judgment that replaces negative emotions such as anger, hatred, contempt and sadness in the affective system to allow for healing. (Augusburger, 1981, Cunningham, 1985 and North, 1987). This explains why Borris, (2003) notes that there are many ways to alleviate the symptoms of suffering and pain in the world, but one way to heal its cause, and the only one way is found in the healing power of forgiveness. However, it constitutes one of the most difficult aspect of human relations. 


\section{Concession}

Concession means cessation from previously held position or act of conceding, or compromising in some way often grudgingly or unwillingly. Nijssen (2013) notes that negotiation process is all about concessions. If the parties in a negotiation will not shift from the pre-negotiation positions held, it will come to a grinding halt. Borris (2003) noted that it is a challenge to one own defences and experiences, as it entails the re-interpretation of events and recognize how their thinking and perception might have been distorted.

Extant literature notes that Concessions are often necessary in negotiation. In order to build good will and reciprocity certain steps such as label your concessions, demand and define reciprocity, make contingent concessions and in installments are essential. In labeling the concession, it is essential that it should be made known that what you a party is given up is costly to them while it emphasizes the benefits to the other side.

Concession calls for flexibility of approach to resolve differences as fixation of opinion cannot but compound the scope of attaining a win-win solution. This explains why De vito (1978) observes that flexibility and willingness to compromise are especially important in conflict situations. The relevance of granting concession in Share/Tsaragi conflict and elsewhere is that people cannot always have their way and the willingness to compromise manifests some level of sincerity in searching for peace as it enhances the chances of trust building. However, concession is often difficult because of ego problems particularly when the issue at stake assumes political, religious or ethnic dimension.

\section{Trust}

One of the major challenges in peace building process is that of trust at every stage. This explains why Notter, (1995) observes that trust and conflict transformation both revolve around the issue of relationship. He describes it as the key factor in any analysis of conflict and fundamental to the relationship building process between the practitioners and the parties in conflict. Trust revolves around three important variables. These are relationship, expectations and behavior. It therefore provides an understanding of how trust works, how it is developed and how people react to trust being broken.

A simple definition of trust according to Notter, (1995) is to count on someone to do as he says he will do. There is the general understanding that expectations are normally the focal point of defining trust and the first element of it is risk. That is, the opposing party will not take undue advantage of the truster's self exposure. Hence, scholars views trust from the cost /benefit analysis where, as observed by Notter, the element of trust counter balances the risk factor.

The existence of mutual trust gives the process of peace-building the necessary and needed support to ensure enduring peaceful co-existence. This invariably creates an enabling environment for peace, fairness and justice to thrive. However, Kelman, (2005) noted that the basic dilemma in resolving conflict is that parties cannot enter into a peace process without some degree of mutual trust, but they cannot build trust without entering into peace process. To overcome the prevalent mutual distrust, he argues the need for reassurance from the parties that called for successive approximation while the third party could serve as repository of trust with the herculean task of building uneasy coalition and the need for mutual reassurance.

\section{Negotiation}

Negotiation constitutes one of the non-violent and out of court means of resolving conflicts. AkpuruAja (2007) notes that it is a mechanism for enhancing communication flows between the conflicting parties as to be able to resolve differences by mutual consent. According to Adekanye (2006), negotiation is defined as:

The art of securing agreements on issue(s) of conflicting or competing interests and values between two or more parties who are interdependent, and who are seeking to maximize their outcome or payoffs through non-violent means or process and based on mutual acceptance of or/and commitment to such a means or process.

Negotiation revolves largely on the use of dialogue as the most important components of conflict resolution. It has the quality of deemphasizing fixation of opinion or views on issue of conflict. It possesses the quality of accommodating the opposing party's view and minimizes the influence of sentiment and fear (Shedrack (2006). It is also anchored on the potentiality of the disputing parties to come together, reason together, and evolve workable solutions to issues of conflict as was the case in Saare/Tsaragi prior to 2000. This explains why the two traditional rulers of the conflicting communities during separate interview rightly or wrongly noted that they had the capacity to resolve their differences given that there was no politicized intervention by the government.

Adekanye (2006) observes that there must be among other things the convergence of interest, readiness for settlement and threats of circumstances or mutual hurting stalemate as preconditions for successful negation. There are two prominent approaches to negotiation, the positional or distributive negotiation through bargaining and collaborative or integrative negotiation. The positional negotiation by bargaining adopts a position of strength rather than weakness for negotiation. This study argues in favour of collaborative negotiation that 
Shedrack (2006) refers to as constructive engagement for conflict management because both the feeling and facts are recognised by the conflicting parties. The goal of the party under this arrangement is to mutually find an acceptable solution to the conflict rather than fault finding.

VII. Presentation of Results

Table 1: Community Sample Distribution

\begin{tabular}{|l|l|l|}
\hline & Frequency & Percent \\
\hline Tsaragi & & \\
Saare & 200 & 50 \\
Total & 200 & 50.0 \\
\hline
\end{tabular}

Source: Researcher's fieldwork (2011/2012)

The table 1 above revealed the community sample distribution as consisting of two hundred respondents each in Saare and Tsaragi communities given, a total of four hundred respondents covered in the exercise.

Table .2: Respondents' View on Injury Suffered

\begin{tabular}{|c|l|l|}
\hline & Frequency & Percent \\
\hline Yes & 308 & 77.0 \\
\hline No & 68 & 17.0 \\
\hline I don't know & 24 & 6.0 \\
\hline Total & 400 & 100.0 \\
\hline
\end{tabular}

Source: Researcher's fieldwork, (2011/2102)

Table 2 revealed that $77 \%$ of the respondents suffered injury, while $17 \%$ did not. Further breakdown of the result at the community level revealed that $82.5 \%$ and $71.5 \%$ in Saare and Tsaragi respectively said they suffered injury, while $13 \%$ in Saare and $21 \%$ said they did not.

Table 3: Satisfaction with Government Latest Decision

\begin{tabular}{|l|l|l|}
\hline & Frequency & Percent \\
\hline Yes & 107 & 26.8 \\
\hline No & 222 & 55.5 \\
\hline I don't know & 71 & 17.8 \\
\hline Total & 400 & 100.0 \\
\hline
\end{tabular}

Source: Researcher's fieldwork (2011/2013)

Table 3 revealed that only $26.8 \%$ of the respondents were satisfied with the latest government resolution efforts. $55.5 \%$ of the respondents disagreed, while those who were neutral were $17.8 \%$.

Table 4: Trusting Relationship

\begin{tabular}{|l|l|l|}
\hline & Frequency & Percent \\
\hline Yes & 130 & 32.5 \\
No & 191 & 47.8 \\
I don't know & 79 & 19.8 \\
Total & 400 & 100.0 \\
\hline
\end{tabular}

Source: Researcher's fieldwork (2011)

Table 4 revealed that 32 percent of the respondents were willing to trust one another, while 47.8 per cent disagreed and 19.8 percent were undecided.

Table 5: Support for Peaceful Coexistence

\begin{tabular}{|l|l|l|}
\hline & Frequency & Percent \\
\hline Yes & 290 & 72.5 \\
No & 56 & 14.0 \\
I don't know & 54 & 13.5 \\
Total & 400 & 100.0 \\
\hline
\end{tabular}

Source: Researcher's fieldwork (2011/2012)

Table 5 revealed that $72.5 \%$ of all the respondents preferred peaceful co-existence, while $14 \%$ disagreed and $13.5 \%$ were neutral.

Table 6: Willingness to Forgive

\begin{tabular}{|l|l|l|}
\hline & Frequency & Percent \\
\hline Yes & 298 & 74.5 \\
No & 70 & 17.5 \\
I don't know & 32 & 8.0 \\
Total & 400 & 100.0 \\
\hline
\end{tabular}

Source: Researcher's fieldwork (2011/2012) 
The result on table. 6 revealed that 74.5 percent of the respondents was willing to forgive one another, while 17.5percent disagreed and 8percent remained indifferent.

Table 7: Concession

\begin{tabular}{|c|c|c|}
\hline & Frequency & Percent \\
\hline Yes & 335 & 83.8 \\
\hline No & 39 & 9.8 \\
\hline I don't know & 26 & 6.5 \\
\hline
\end{tabular}

Source: Researcher's fieldwork (2011/2012)

83.3 percent of the respondents as contained on Table 7 were prepared for concession to achieve peaceful resolution of the conflict.

Table 8: Support for Peaceful Coexistence

\begin{tabular}{|l|l|l|}
\hline & Frequency & Percent \\
\hline Yes & 290 & 72.5 \\
No & 56 & 14.0 \\
I don't know & 54 & 13.5 \\
Total & 400 & 100.0 \\
\hline
\end{tabular}

Source: Researcher's fieldwork (2011)

The result on Table 8 above found that 72.5 percent of the respondents supported peaceful coexistence between the two communities.

\section{Discussion of Results}

The study found that the ethno-communal boundary conflict started to assume violent dimension in 2000 though evidences of structural and cultural violence became pronounced in 1976 with the creation of Ifelodun local government, Saare as the Headquarters. The first recorded direct violence occurred on June 9-11, 2000 while the second was from July $11-14$, 2000, both recorded huge human casualties and massive destruction of properties. The third violent conflict occurred on November 2-3, 2008 leading to the death of eight people in Saare and one in Tsaragi as well as the destruction of sixty six buildings though compensation was paid on each instance of direct violence by the State government (Justice AbdulGafar Judicial Commission of Inquiry of 2009 into Saare/Tsaragi conflict).

The study found that 77 percent of the respondents suffered injury while 74.5 percent were willing to forgive each other and 72.5percent preferred peaceful coexistence between the two communities. The process of peace building in respect of Saare/Tsaragi could be achieved as the study found that they were willing to forgive each other. Vine (1985) however advocates that forgiveness must be unconditional. The findings agreed with Augusburger, (1981), Cunningham, (1985) and North, (1987) Richard,(1988) that forgiveness involves a process which required a change in one's perception, and judgment that replaces negative emotions such as anger, hatred, contempt and sadness in the affective system to allow for healing that is required for peace building. This explains why Borris, (2003) notes that there are many ways to alleviate the symptoms of suffering and pain in the world, but one way to heal its cause, and the only one way is found in the healing power of forgiveness.

The study found that 83.8 Percent of the respondents were prepared to grant concession while this might explain why 72.5 percent preferred peaceful coexistence between the two communities. The study observed that without the granting of concession, there is no hope for successful peace building. Since significant majority of the respondents were prepared for granting of concession, there is the need for necessary institutional arrangement to be put in place political, social and structural peace building to be conducted through integrative negotiation. This position agrees with Nijssen (2013) and Malhotra, (2006) that negotiation process is all about concessions and essentially required to build goodwill.. the process becomes endangered If the parties in a negotiation will not shift from the pre-negotiation positions held. This explains why Borris (2003) sees it is as a challenge to one own defences and experiences, as it entails the re-interpretation of events and recognize how their thinking and perception might have been distorted

In addition, the study found that 32 percent of the respondents were willing to trust one another, while 47.8 per cent disagreed and 19.8 percent were undecided. The finding revealed the fear and danger associated with trusting relationship. The mere fact that victims of previous conflict can't but relive their past and how their trust had been betrayed teaches a lesson concerning undue self exposure to known enemies in the name of trust. It further reflects how complex this issue of trust is. While it is easier for conflicting parties to forgive and grant concession, same is not true of trusting relationship.

The result agrees with Notter (1995) that the opposing party often entertain fear that the other party will not take undue advantage of the truster's self - exposure. This position justify the views of Kelman, (2005) that the basic dilemma in resolving conflict is that parties cannot enter into a peace process without some degree of mutual trust, but they cannot build trust without entering into peace process. The fact the only 26.8 percent of the respondents were satisfied with the government resolution efforts questioned the integrity of the State 
government and the willingness to trust the conflicting party. Therefore, trusting relationship no matter how difficult it sounds is required for peace building.

The implications of these results on other nations emerging from direct violence and are embarking on peace building are:

- That it is easier for conflicting parties to forgive and grant concession but it is difficult to trust each other. Therefore, peace workers in Africa and Middle East need to put more efforts into social and structural peace building as major concentration in the past was on political peace building.

- That communities or groups engaging in inter ethnic conflict could be mobilized or empowered to contribute meaningfully to peace building process and manage their differences through existing local mechanisms as confirmed by the Ndakpoto of Tsaragi and Olupo of Saare.

- That government in Africa should minimize politicization of issues of conflict and reconsider the adoption of security approach to peace rather in preference of peace approach to security.

- Stemming from the above, that there is urgent need for African governments and beyond to understand and appreciate that pacification of conflicting parties through provision of relief materials and implementation of their own agenda will not achieve true reconciliation that is required for successful peace building.

- That strong political will is required of governments in resolving intra and inter ethnic conflicts as this was glaring lacking in most nations of Africa. This position agrees with Nwolise (2005) cited in Albert (2005:165) noted that the Aguleri - Umuleri episode exposed:

The weakness and failures of colonially inherited mechanisms and processes of conflict prevention, management and resolution, the inadequacies of the police in handling certain forms of conflict, the inadequacies of the courts and government commissions of inquiries as even the government itself lacks the political will to implement the recommendations of the commissions.

The same is true of nearly all ethno-communal conflicts in Nigeria and beyond as rightly observed by Bogoro (2009) that:

Honestly, I said it and I am repeating it again that the bold implementation of the Yelwa Kagadama Judiciary Commission white paper is commendable and timely, because the non-implementation of white papers in many conflicts in the past is responsible for the recurrence of ethno-religious crisis in the state.

\section{Conclusions \& Recommendations.}

The study concludes that most of the burning issues of conflict in Africa and beyond are not insurmountable provided among others, that attention is given by peace agents to mending the cracks in the broken relationship. This study revealed that trust building is the most difficult issue to contend with in peace building as the non inclusive approach often adopted by government made peace efforts not to accomplish the desirable results. The demonstrated willingness to forgive, grant concession will open the channels of sincere communication in normalizing relationships.

As an alternative dispute resolution mechanism the study recommends the depoliticization process that requires conflict group leaders to agree not to involve the government in public policy areas which impinge upon the segments' values or interests as found in Lebanon. This could be achieved through collaborative negotiation that will be inclusive in line with the wishes of the two traditional rulers rather than imposed treaties following government strict agenda.

The study recommends that efforts should be concentrated largely on minimizing resurgence of direct violence through effective monitoring of relationship to identify early warning signal and allaying the fear associated with the issues involved. This is the responsibility political leaders, traditional rulers, government and the entire citizenry.

The study further recommends that the issues and parties to the conflict should be carefully identified in every instance of conflict and be accommodated in the peace building process while efforts must not be directed only at pacifying the victims through payment of compensation at the expense of reconciliation.

Also, Kwara State government must ensure that the basis for the peace building of Saare/Tsraragi conflict must take cognisance of the provisions of Section $7 \& 8$ of the 1999 Constitution of the Federal Republic of Nigeria. To achieve this, the report of the Technical Committee of the Kwara State Boundary Committee that established the boundaries when the Local Governments were created in 1976 that was set aside by the previous government must be revisited (CN 18.3//111/503 of January 13, 2010). Where such arrangement may not be able to work effectively, the two communities and the Local Governments must be taken into confidence with a view adjusting the boundary following the constitutionally provided channels so as not to submit the process to future litigation..

Furthermore, the Government should reconsider the adoption security approach to peace This will minimize the excessive deployment of security forces that lack adequate knowledge of peace building or peace 
keeping and eventually turn out to constitute cog in the will of peace building as their tactics often fail to separate peace building process from fighting enemies in the battle field..

Lastly, the study recommends the setting up of the Truth and Reconciliation Committee where parties will freely confess their wrong doings and ask for forgiveness. This might re-awaken old wound but after the confession and weeping, nerves will calm down and inner peace can be restored to make forgiveness, granting of concession and trust building possible.

\section{References}

[1]. Adekanye, J. B (2006). The Art and Science of Negotiation. A paper presented a Seminar on ECOWAS and Economic Partnership Agreement Negotiation with EU, Organized by the Policy Analysis and Strategic Planning Unit, ECOWAS Executive Secretariat, Abuja, July 20 .

[2]. Alao, D. (2012). An Assessment of Ethno-Communal conflicts in Saare/Tsaragi Communities of Kwara State, Nigeria. An Unpublished Ph.D. Thesis. Ilishan, Babcock University.

[3]. Akpuru-aja, A. (2007). Basic Cocncepts. Issues and Strategies of Peace and Conflict Resolution. Enugu: Keny \&Brothers Ent. (NIG).

[4]. Albert, I. O. (2005). eds. Perspectives on Peace and Conflict in Africa. Ibadan :Archers Press.

[5]. Anifowose, R. (2006). Challenges of Sustainable Democracy in Nigeria, Ibadan: JohnArchers Publishers.

[6]. Augsburger, D (1981). Caring Enough Not to Forgive. Scottsdale, AZ: Herald. Bawer, B. (2007) “The Peace Racket”. City Journal, Summer. Retrieved From http://www.cityjournal.org/html/17_3_peace-racket_html.

[7]. Bogoro, S. (2009) “Indigeneship Based on Residency will Stem Religious Crises" Discussion in News, politics and Current Affairs. March.

[8]. Bonar, C. A. (1989). Personality theories and asking forgiveness. Journal of Psychology and Christianity, 8 (1), $45-51$. orris, E. R. (2003). "The Healing Power of Forgiveness". Occasional Paper Number 10, Institute of Multi-Diplomacy Retrieved from http://www.quest.com/gogglescholar.gst.

[10]. Accessed August 8, 2012

[11]. Boulding, K.E (1977). "Twelve Friendly Quarrel with Johan Galtung". Journal of Peace Research Vol.14. No.1 pp 75-86 retrieved from http;//www.Jsttor.org/pss/423312. Accessed Sept. 21, 2011.

[12]. Boutros- Ghali , B. (1995). An Agenda for Peace. New York: United nations.Bowman, I. G. (2003) Theory and Literature Survey of the Phenomena of Forgiveness and Self- Forgiveness cited in http://upetd.up.ac.za/thesis/available/etd-06172004 123504/unrestricted/04chapter4.pdf. accessed August 1, 2012.

[13]. Cunningham, B. B. (1985). "The will to Forgive: A Pastoral Theological View of Forgiving". Journal of Pastoral Care; 39(2), 141-149.

[14]. Doyle, M. and Sambanis, N. (2007), "Building Peace: Challenges and Strategies After Civil War,'The United States World Bank Group. Retrieved from http://www/worldbank.org/research/conflict/papers/building.pdf)3

[15]. Enloe, C.H. (1973). Ethnic Conflict and Political Development, Boston: Little Brown and Company.

[16]. Enright, R. \& The Human Development Study Group (1991). The moral development of forgiveness. In W. Enright, R., Gassin, E., \& Wu, C. (1992). "Forgiveness: a developmental view". Journal of Moral Education, 21(2), 99-114.

[17]. Foundation for Inner Peace, (1971) Cited in Borris, E. R. (2003) "The Healing Power of Forgiveness" retrieved from http://www.quest.com/gogglescholar.gst. Accessed August 8, 2009.

[18]. Gurr, T.R. (1970). Why Men Rebel. Princeton, New Jersey: Princeton University Press Haugerudbraaten,H (2006). "Peacebuilding": Six Dimensions and Two Concepts,Institute ForSecurity Studies". Retrieved from http://www.iss.co.za/Pubs/ASR/7No6/Peacebuilding.html)

[19]. Galtung, J. (2000). Conflict Transformation by Peaceful Means. New York: United Nations.

[20]. Galtung, J. (2010). 'Peace by Peaceful Conflict Transformation-Transcend model' in Webel, C \& Galtung, J. (2010). A Handbook ofPeace: A Conflict Studies. New York:Routledge.

[21]. Justice AbdulGafar Judicial Commission of Inquiry of 2009 into Saare/Tsaragi conflict Kay, B (2009)."Barbarians within the Gate", National Post, February 18. Retrieved From http://www.barbarakay.ca/index.php?option=com_content\&view article.id+20. Accessed on September 21, 2011.

[22]. Kaminer, D(2001) The Truth and Reconciliation Commission in South Africa: Relation to Psychiatric Status and Forgiveness among Survivors of Human Rights Abuses. The British Journal of Psychiatry178: 373-377. Cited in http://bjp.rcpsych.org/search?author1=DEBRA+KAMINER\&sortspec=date\&submit=Submit.

[23]. Kolna, A. (1973-74) "Forgiveness". Proceeding of the Aristotelian Society 74, 91-96 cited in Borris, E. R. (2003). "The Healing Power of Forgiveness". Occasional Paper Number 10, Institute of Multi-Diplomacy Retrieved from http://www.quest.com/gogglescholar.gst. Accessed August 8, 2012.

[24]. Krasner, S. D. (2004) "Sharing Sovereignty. New Institutions for Collapsed and Failing States," International Security, $29,2$.

[25]. Lederach, J. P. (1995),Preparing For Peace: Conflict Transformation across Cultures. New York: Syracuse University Press

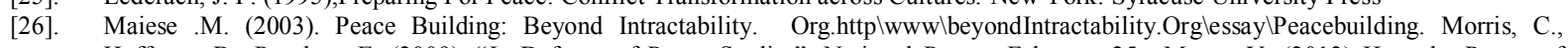
Hoffman, B., Peachey, E. (2009). "In Defense of Peace Studies", National Post, February 25,mMusser,V. (2012) How the Power of Forgiveness Can Heal Your Life cited in http://www.2012-spiritual-growth-prophecies.com/power-of-forgiveness.html.Accessed July24,2012.

[27]. Nicolaides, D. (2008) Employing Conflict Transformation in Understanding the Cyprus Problem:Prospects and Instruments in Conflict Transformation. A Master of Arts Degree Thesis in Peace and Conflict Studies. (Unpublished) European University Centre for Peace Studies p.11.

[28]. North, J. (1987). "Wrongdoing and Forgiveness". Philosophy 62 (242):499 - 508

[29]. Notter, J. and Diamond, L. (1996) "Building Peace and Transforming Conflict: Multi Track Diplomacy in Practice". Occasional Paper Number 7, October, Retrieved fromhttp://www.imtd.org/pdfs/OP7.pdf

[30]. Osaghae, E. (2005) 'Violence in Africa: State, Ethnic and Regional Dimension'. Retrieved fromhttp:// books google. Com. UK/ books? Id= og YDBob OHUEC Doctrines."

[31]. Reychler, L. (2001). "From Conflicts to Sustainable Peacebuilding. Concepts and Analytical Tools in Peacebuilding" in Reychler, L \& Paffenholz, T. (2001) eds. A Field Guide. Colorade: Lynne Rienner Publishers.

[32]. Shedrack, G.B (2006). Eds. "The Methods of Conflict Resolution and Transformation" in Introduction to Peace and Conflict Studies in West Africa Ibadan:Spectrum Books Limited Small, D. (ND) Design for Christian Marriage, cited in http://www.christianity.co.nz/forgive2 Accessed July 2, 2012

[33]. Zartman, W. I (2000)(ed) Traditional Cures for Modern Conflicts, African Conflict “Medicine". London : Lynne Rienner Publishers. 